\title{
THERMAL TESTING OF THE LIGHT PIPE PROTOTYPE
}

\author{
Ayodeji Omishore - Miloš Kalousek - Petr Mohelník*
}

Faculty of Civil Engineering, Brno University of Technology, Veveri 95, 60200 Brno, Czech Republic

\begin{tabular}{l} 
ARTICLE INFO \\
\hline Article history: \\
Received: 20.10 .2017$. \\
Received in revised form: 26.1.2018. \\
Accepted: 5.2.2018. \\
\hline Keywords: \\
IR thermography \\
Temperature distribution \\
Light pipes \\
\hline DOI: http://doi.org/10.30765/er.39.3.09
\end{tabular}

\section{Introduction}

\subsection{About Light Pipe Systems}

Trends of solar energy applications in buildings brought systems of light pipes [1]. Light pipes transmit solar radiation into interiors. The light pipes can improve daylight level in internal parts of buildings which is very important for indoor visual comfort in buildings [2,3]. In spite of many positive aspects for day lighting, the light pipes installations in building constructions can cause condensation problems. It is caused because of the light pipe metal tube installed in thermally insulated constructions $[4,5]$. The experimental results indicated that dust and condensation worsen the day lighting performance of solar light pipes [6].

On the other hand, solar radiation affecting light pipes could represent potential risk of the system overheating. Overheating is due to the solar gain through the building fabric and transparent openings [7]. Solar radiation is transmitted through light pipes due to multi-reflections. It is inevitably partly absorbed on the light pipe components - roof dome, tube, and diffuser. Energy of absorbed solar radiation is distributed along the pipe, and it influences its temperature profile.

\begin{abstract}
:
A light pipe prototype with a concentrating mirror parabolic head was tested for temperature profiles. The purpose of the testing was to find maximal temperature and estimate potential problems for overheating in the position of the pipe installation into roof structures. Infrared thermography monitoring of the light pipe prototype and temperature measurements give overview about the light pipe system temperature distribution. It was proven that the light pipe head temperature was increased for more than $100^{\circ} \mathrm{C}$ in thermally insulated structure under intensive infrared radiation.
\end{abstract}

Various types of light pipe systems have applications in buildings [8]. Common passive light guiding tubes [9] are combined with ventilation pipes [10]. Special types of light pipes with roof mirrors and parabolic concentrators increase both light transmittance and solar gain through the light pipe $[11,12]$. The light pipes with concentrating mirrors and collectors might be very efficient but high solar gain could significantly increase temperature which might be a potential problem for their installations on roofs. Increased temperature of a light pipe with the roof solar concentrating system could lead into potential fire risks as it is known from the PV collector roof installations $[13,14]$. The potential overheating problem was the reason why a new light pipe prototype [15] was thermally tested.

\subsection{Thermal Evaluations of Light Pipes}

Light pipes have been subject of research. The research has been focused mainly for daylight evaluations [16-20]. Also, solar heat gains [21] were evaluated for tubular daylight devices. Less investigation was done for thermal evaluations of these systems. A literature review was done for the light pipe thermal testing. The principles of heat transfer through tubular systems were studied

\footnotetext{
* Corresponding author.

E-mail address: mohelnik.p@fce.vutbr.cz.
} 
$[22,23]$. The thermal evaluation of light pipes is referenced for models or real installations. The experiments were completed for thermal characteristics determination of light pipes of specific dimensions $[24,25]$. Studies of light pipes thermal performance under tropical climatic conditions were solved [26]. Heat transfer and natural ventilation in light pipes were studied on models. Computer fluid dynamic simulations aimed at the light pipe thermal profiles were analyzed [27-30]. The simulations and experimental studies were carried out for integrated daylight-ventilation pipes [31-33]. Energy of solar radiation absorbed into the light pipe was specified for the EnergyPlus software simulations [34]. The thermal properties of glass samples are important values for the energy evaluations $[35,36]$.

The article is focused on a thermal testing of an atypical light pipe prototype with a parabolic concentrator. The thermal analysis of the light pipe gives information about conditions of their installations on roofs. The purpose for the testing was to evaluate how temperature of the tube is increasing in a response to solar radiation affecting the light pipe. The contribution is to test surface temperature distribution and specify temperature profiles of the light pipe for specification of overheating problems.

\section{Experimental investigation}

The tested light pipe was placed in a supporting structure. The box of dimensions $1.5 \mathrm{~m} \times 1.5 \mathrm{~m}$, being height $1.5 \mathrm{~m}$ is used for the light pipe installation.

The light pipe consists of the concentrating head with metal parabolic mirror (on the top), metal reflective tube (in the middle, length $0.6 \mathrm{~m}$, diameter $0.52 \mathrm{~m}$ ), and transparent diffuser at the end of the system, Fig. 1. The parabolic mirror and tube are completed of metal aluminium alloy sheets with mirrored internal surface. Thin silver layer sputtered on the aluminium substrate gives high surface reflectance of the light pipe [15].

\subsection{Infrared Thermography}

The temperature distribution on surfaces of the light pipe was monitored due to temperature measurements and infrared thermography [37-39] monitoring. The temperature profiles were tested as provided in laboratory conditions. The light pipe was exposed to radiation of an infrared lamp of dimensions $200 \times 750$ × 400 mm, Fig. 2 .

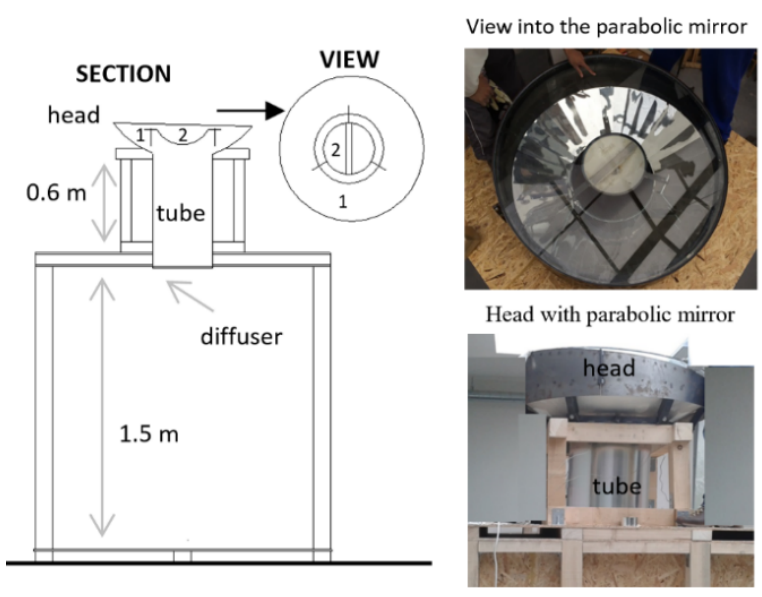

1 - primary parabolic mirror, 2 - secondary mirror

Figure 1. Light pipe prototype installation.

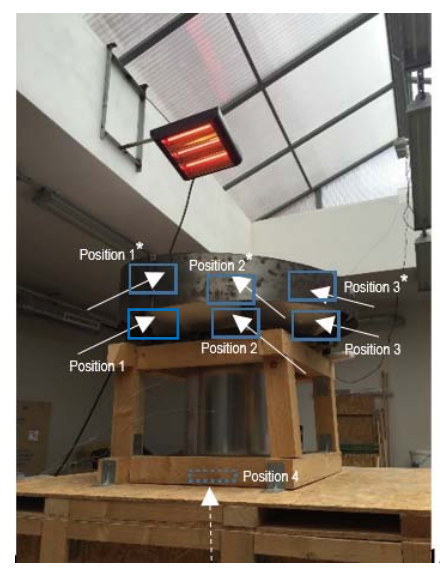

a)

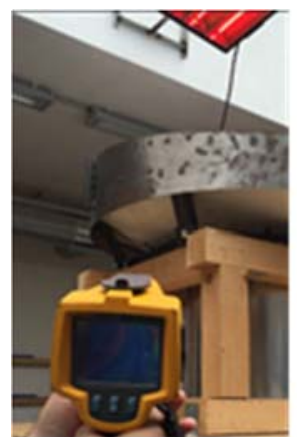

c)

d)

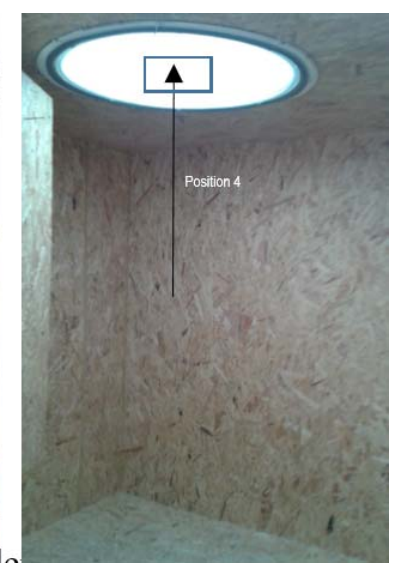

b)

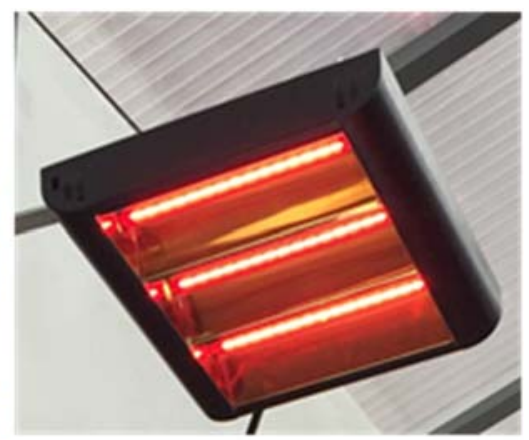

Figure 2. Photograph of the light pipe under the IR lamp installation; a) Positions 1,2,3 directions of IR camera monitoring, position 4 - on the internal diffuser, positions $1^{*}, 2^{*}, 3^{*}$ - on the metal rim of the light pipe head, $b$ ) view to the light pipe diffuser (inside the box), c) IR camera monitoring, d) IR lamp [40]. 
The lamp consists of three linear tubes of power 1500 $\mathrm{W}$ per each. The total power of the IR lamp is $4.5 \mathrm{~kW}$ [40]. The lamp photometric heat distribution is $11 \mathrm{~m}$ $\mathrm{x} 4.5 \mathrm{~m}$ [40]. The lamp simulates infrared radiation of solar shining. For common technical purposes the intensity of solar radiation affecting building surfaces and solar collectors is considered about $1000 \mathrm{~W} / \mathrm{m}^{2}$ which is installed (nominal) power for defined conditions according to ESTIF [41]. The ratio of the IR lamp power of exposed areas is $4.5 \mathrm{~kW}$ per area of the light pipe concentrator head $1.77 \mathrm{~m}^{2}$, cross sectional area of the tube is $0.21 \mathrm{~m}^{2}$.

Infrared thermography was done with IR camera ThermaCAM PM695, the Flir system. The infrared monitoring system consists of an IR camera with a built-in $24^{\circ}$ lens, IR images - over 300,000 pixel resolution at $640 \times 480$ [42]. The IR camera monitoring was completed for different positions (Fig. 2) round the light pipe parabolic head to complete entire thermal profile of the exposed parts of the light pipe. Distance between the IR camera objective and the measurement is from $1 \mathrm{~m}$ for detail monitoring and $2 \mathrm{~m}$ for overall views. The infrared thermography monitoring was carried out for two time intervals of the infrared lamp activation - for 10 minutes (it simulates a short period of insolation) and 100 minutes (long time activation). The purpose of the long-time thermal activation is to estimate how much the light pipe surfaces' temperature could rise to the steady state thermal conditions.

The monitoring was completed for ambient temperature of $27^{\circ} \mathrm{C}$ (ambient average temperature of the air and surfaces close to the light pipe experimental setup). An average emissivity of neighbouring surfaces was 0.95 (surfaces of wall and ceiling plasters and facing and floor cement screed finishing). Emissivity of mirrored surfaces of the light pipe prototype is 0.05 [43]. The thermal monitoring was compared to infrared thermography monitoring for heat transfer models [44] and the previous studies of computer simulations of light pipes thermal profiles $[27,28]$.

\subsection{Temperature Measurement}

Temperature profiles were monitored by thermocouples connected with data-logger Almemo, Alhborn, $0.1 \mathrm{mV} /$ digit, accuracy $\pm 0.02 \%, \pm 1$ digit [45]. Thermocouples of type Ni-Cr-Ni of type $\mathrm{K}$ (measuring range -200 to 1200) [46] were used for the measurement. Total number of eight thermocouples was used. Seven sensors were installed on the light pipe model and the eighth sensor monitored indoor temperature in the laboratory. Positions of the light pipe thermocouples installation are shown in Fig. 3.

Temperatures were measured for one-minute intervals. Temperature measurements were completed with the laboratory controlled apparatuses. Indoor temperature data were controlled with temperature data from laboratory thermometer. The compared temperatures vary in interval $+/-2^{\circ} \mathrm{C}$. Some differences in temperature monitoring could be caused because of aging of the thermocouple or in case that the thermocouple material is not homogenous.

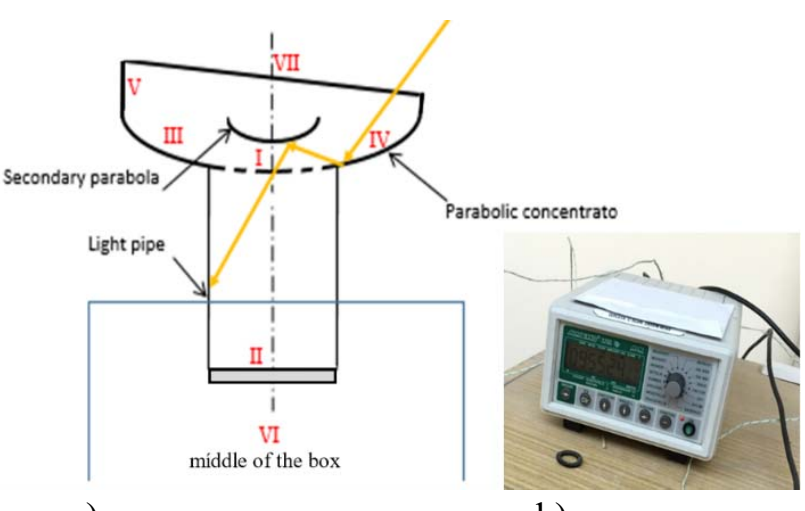

a)

b)

Figure 3. Thermal sensors in the light pipe profile; a) I-VII positions of the thermal sensors installation; b) data logger Almemo for thermal sensors.

\subsection{Insulated Light Pipe}

The infrared thermography and temperature measurements were also carried out for the light pipe with additional thermal insulation $10 \mathrm{~cm}$ round the upper part of the light pipe in the contact with the parabolic concentrator, Fig. 4. The thermal insulation was used to simulate the real installation in thermally insulated building constructions.

\section{Results and Discussion}

\subsection{Infrared Thermography}

Infrared photographs view of the light pipe installation without thermal insulation observed for a short and long term monitoring are shown in Fig. 5. It seems that temperatures do not exceed $50^{\circ} \mathrm{C}$. 


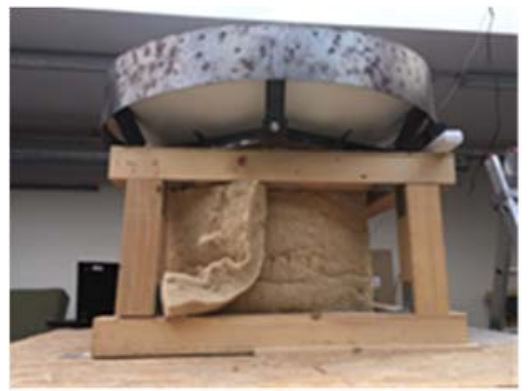

Figure 4. Photograph of the light pipe with additional thermal insulation (mineral wool).

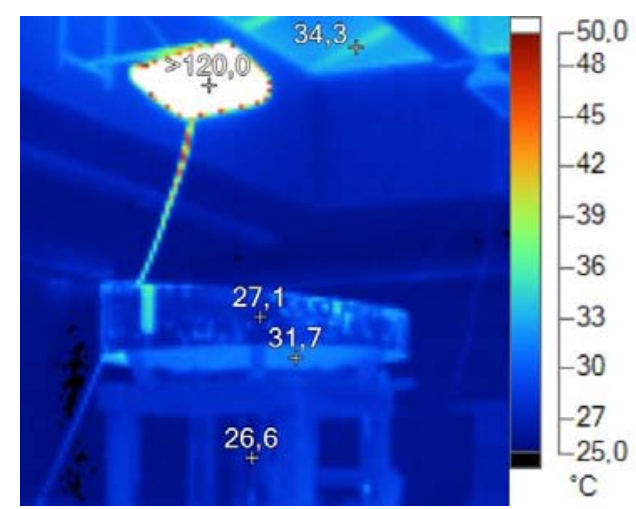

a)

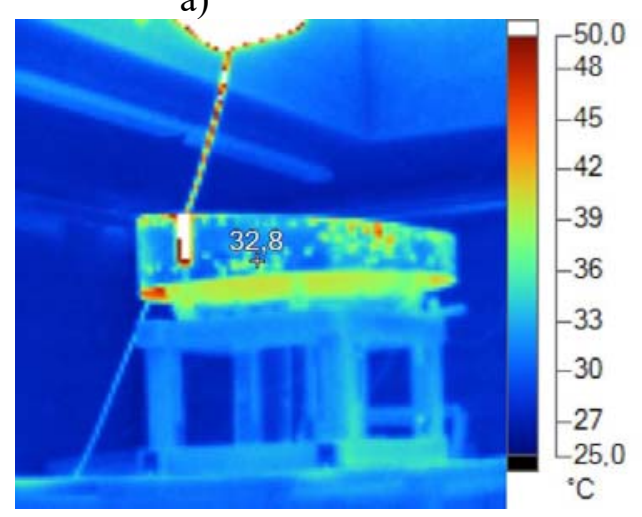

b)

Figure 5. IR thermography - distant view of the whole construction of the light pipe $(2 \mathrm{~m})$; a) Short term thermal activation, 10 minutes, b) Long term thermal activation, 100 minutes.

IR photographs of the light pipe without insulation monitored in details for a short time activation from distance $1 \mathrm{~m}$ are shown in Fig. 6 in Positions 1, 2, 3 and 4 (positions are shown in Fig. 2).

IR photographs of the light pipe without insulation monitored in details for a long time IR lamp activation from distance $1 \mathrm{~m}$ are shown in Fig. 7 in Positions 1, 2, 3 and 4 (positions see Fig. 2).
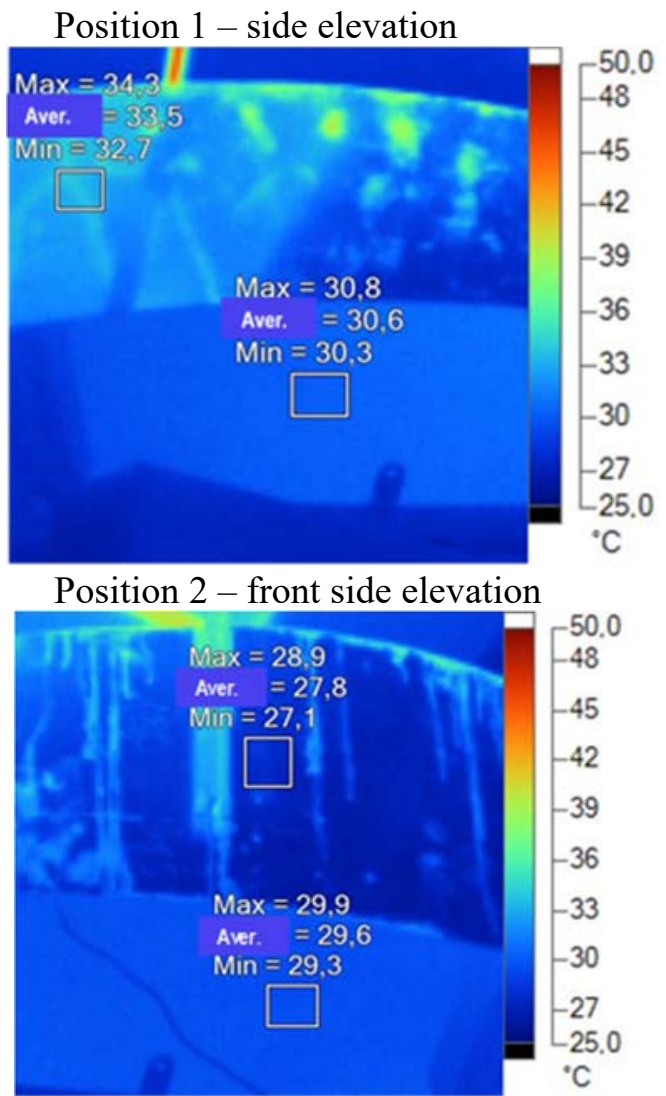

Position 3 - opposite side elevation
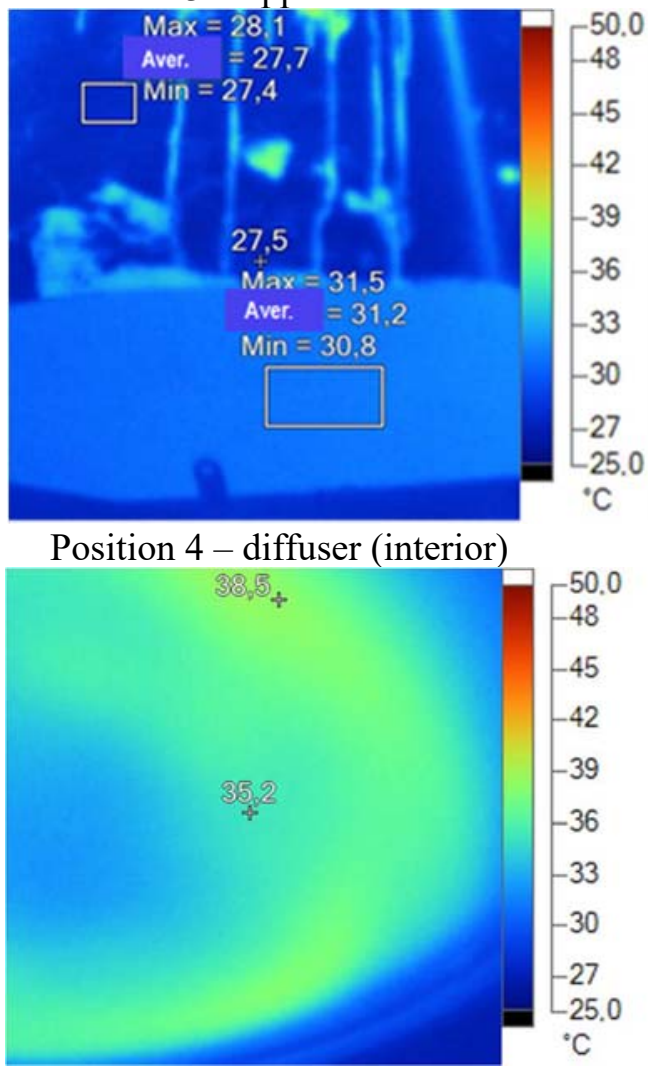

Figure 6. IR thermography of the light pipe head after 10 minutes activation of the IR lamp. 

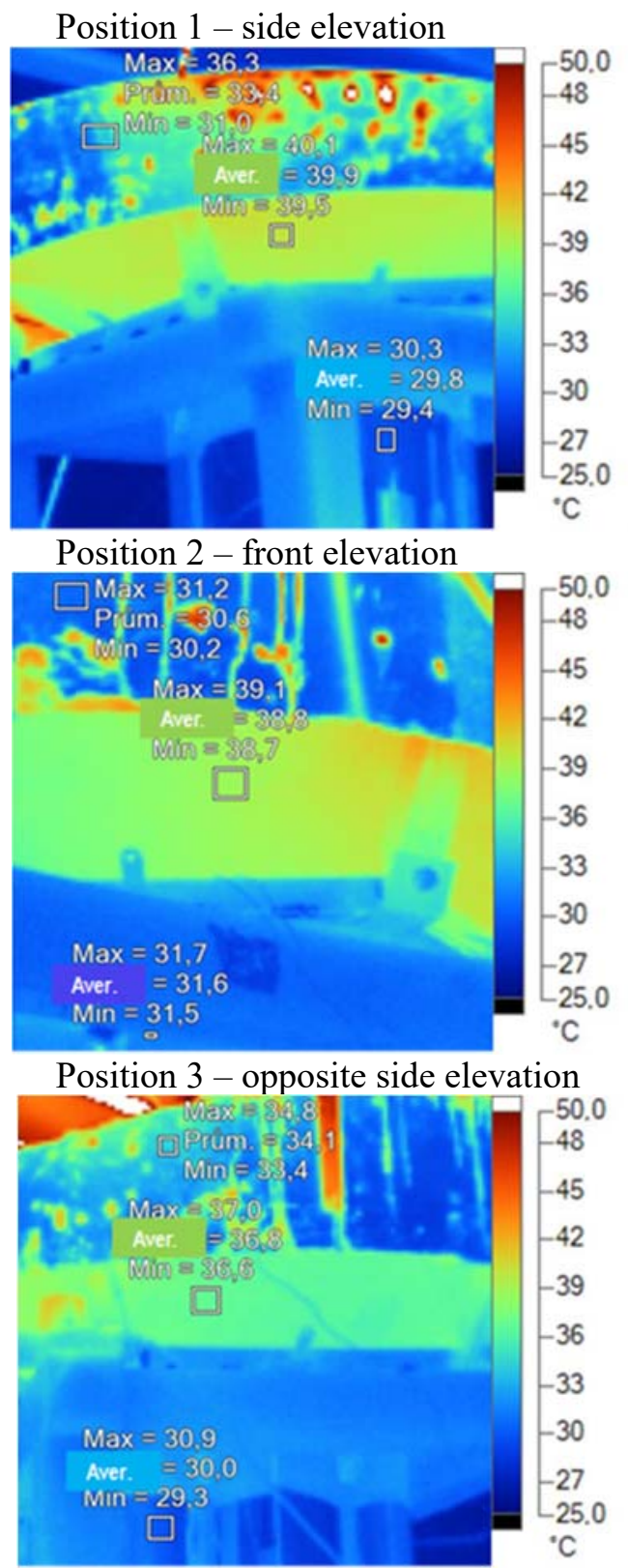

Position 4 - diffuser (interior side)

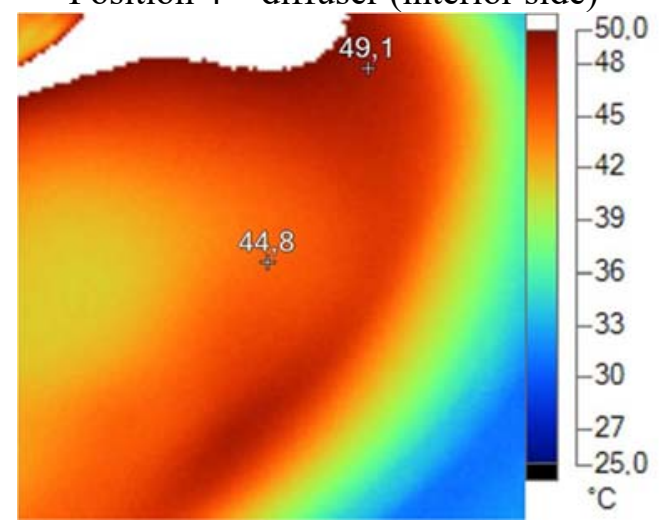

Figure 7.IR thermography of the light pipe head after 100 minutes activation of the IR lamp.
The results of the IR thermography for the light pipe monitoring from Fig. 6 and 7 are summarized in Table 1.

IR photographs of the light pipe with thermal insulation monitored in specified details for the long time activation from distance $1 \mathrm{~m}$ are shown in Fig. 8.

The short time thermal activation shows infrared thermography photographs in Fig. 6: Temperature on the concentrator head varies from $27.1{ }^{\circ} \mathrm{C}$ (minimal temperature, Position 2) to $34.3{ }^{\circ} \mathrm{C}$ (maximal temperature, position 1). The light pipe's diffuser temperature distribution was monitored from position 4 (diffuser surface temperature monitored in the box). The temperature in the center of the diffuser was $35.2^{\circ} \mathrm{C}$, and temperature at the edge of the diffuser close to the metal rim was slightly higher, $38.5^{\circ} \mathrm{C}$.

The long-time IR lamp activation brought higher temperature profiles, Fig. 7. The temperature rises on the light pipe surface up to $40^{\circ} \mathrm{C}$. Results of the surface temperature monitoring of the non- insulated light pipe are summarized in Table 1.

The infrared thermography shows significant temperature rise in case of the insulated light pipe under the long-term thermal activation, Fig. 8. The temperature of the insulated tube was increased for $74^{\circ} \mathrm{C}$. The surface temperature on the head was increased for more than $100{ }^{\circ} \mathrm{C}$, in some parts more than $120^{\circ} \mathrm{C}$. There is a big temperature difference between the lower side of the parabolic concentrator with temperature about $40^{\circ} \mathrm{C}$ and the top of the mirrored parabola with temperature about $100^{\circ} \mathrm{C}$ and even more, Fig. 8 and Table 2.

\subsection{Temperature Measurement}

The temperature profile in the light pipe was also monitored for the time of the IR lamp activation. Thermal sensors connected to the data logger were installed into the light pipe profile for continual thermal monitoring, Fig. 9. As expected the high temperature is in the box which is a non-ventilated space. The graph of the temperature profile measures 24/04/2016 is for the thermally insulated light pipe. The temperature drop M02 sensor (position II) on the second day (26/04/2016) was caused because of the thermal insulation mounting on the light pipe surface (at 11:30). Less infrared radiation has been absorbed into the pipe from the external side because it is thermally insulated. Parabolic concentrator surface temperature rise is for about $16^{\circ} \mathrm{C}$ to $18^{\circ} \mathrm{C}$. 
Temperature close to the glass cover on top of the light pipe system has increased slowly at the beginning, but finally the temperature on the glass surface has increased for $13^{\circ} \mathrm{C}$ to $15^{\circ} \mathrm{C}$, compared to the initial temperature at the start of the experiment. The temperature measurements on thermocouple
(M01) give the air temperature over the parabolic head, whilst the thermography shows temperatures on the parabolic head surface. The correlation between temperatures inside the box and temperature close to the light pipe head is shown in Fig. 10

Table 1 Temperature distribution on the light pipe - positions 1 and 2 and 3 and 4

\begin{tabular}{|c|c|c|c|c|c|c|c|c|c|c|c|}
\hline \multirow{3}{*}{$\begin{array}{l}\text { Thermal } \\
\text { activation }\end{array}$} & \multicolumn{11}{|c|}{ Surface temperature of the light pipe $\left[{ }^{\circ} \mathrm{C}\right]$} \\
\hline & \multicolumn{3}{|c|}{ Position 1} & \multicolumn{3}{|c|}{ Position 2} & \multicolumn{3}{|c|}{ Position 3} & \multicolumn{2}{|c|}{ Position 4} \\
\hline & maximal & minimal & average & maximal & minimal & average & maximal & minimal & average & central & edge \\
\hline 10 minutes & 30.8 & 30.3 & 30.6 & 29.9 & 29.3 & 29.3 & 31.5 & 30.8 & 31.2 & 35.2 & 38.5 \\
\hline 100 minutes & 40.1 & 39.5 & 39.9 & 37.0 & 36.6 & 36.8 & 39.1 & 38.7 & 38.8 & 44.8 & 49.1 \\
\hline \multirow[t]{2}{*}{$\begin{array}{l}\text { Temperature rise } \\
{\left[{ }^{\circ} \mathrm{C}\right]}\end{array}$} & 9.3 & 9.2 & 9.3 & 7.1 & 7.3 & 7.5 & 7.6 & 7.9 & 7.6 & 9.6 & 10.6 \\
\hline & \multicolumn{11}{|c|}{ Surface temperature of the light pipe $\left[{ }^{\circ} \mathrm{C}\right]$} \\
\hline \multirow{2}{*}{$\begin{array}{l}\text { Thermal } \\
\text { activation }\end{array}$} & \multicolumn{3}{|c|}{ Position $1 *$} & \multicolumn{3}{|c|}{ Position 2* } & \multicolumn{2}{|c|}{ Position 3* } & & \multirow{5}{*}{\multicolumn{2}{|c|}{$\begin{array}{l}\text { Summary: } \\
\text { Temperature rise: } \\
\text { - parabolic concentrator } \\
\text { (Positions } 1 \text { and } 2 \text { and } \\
\text { 3): from } 7.1 \text { to } 9.3^{\circ} \mathrm{C} \\
\text {-metal rim of the } \\
\text { concentrator (Positions } \\
\left.1^{*} \text { and } 2^{*} \text { and } 3^{*}\right) \text { : from } \\
2 \text { to } 7^{\circ} \mathrm{C} \\
\text {-diffuser (inside of the } \\
\text { box) from } 9.6 \text { to } 10.6^{\circ} \mathrm{C}\end{array}$}} \\
\hline & maximal & minimal & average & maximal & minimal & average & maximal & minimal & average & & \\
\hline 10 minutes & 34.3 & 32.7 & 33.5 & 28.9 & 27.1 & 27.8 & 27.1 & 27.4 & 27.7 & & \\
\hline 100 minutes & 36.3 & 31.0 & 33.4 & 34.8 & 34.1 & 34.4 & 31.2 & 30.2 & 30.6 & & \\
\hline $\begin{array}{l}\text { Temperature rise } \\
{\left[{ }^{\circ} \mathrm{C}\right]}\end{array}$ & 2.0 & - & - & 5.9 & 7.0 & 6.6 & 4.1 & 2.8 & 2.9 & & \\
\hline
\end{tabular}
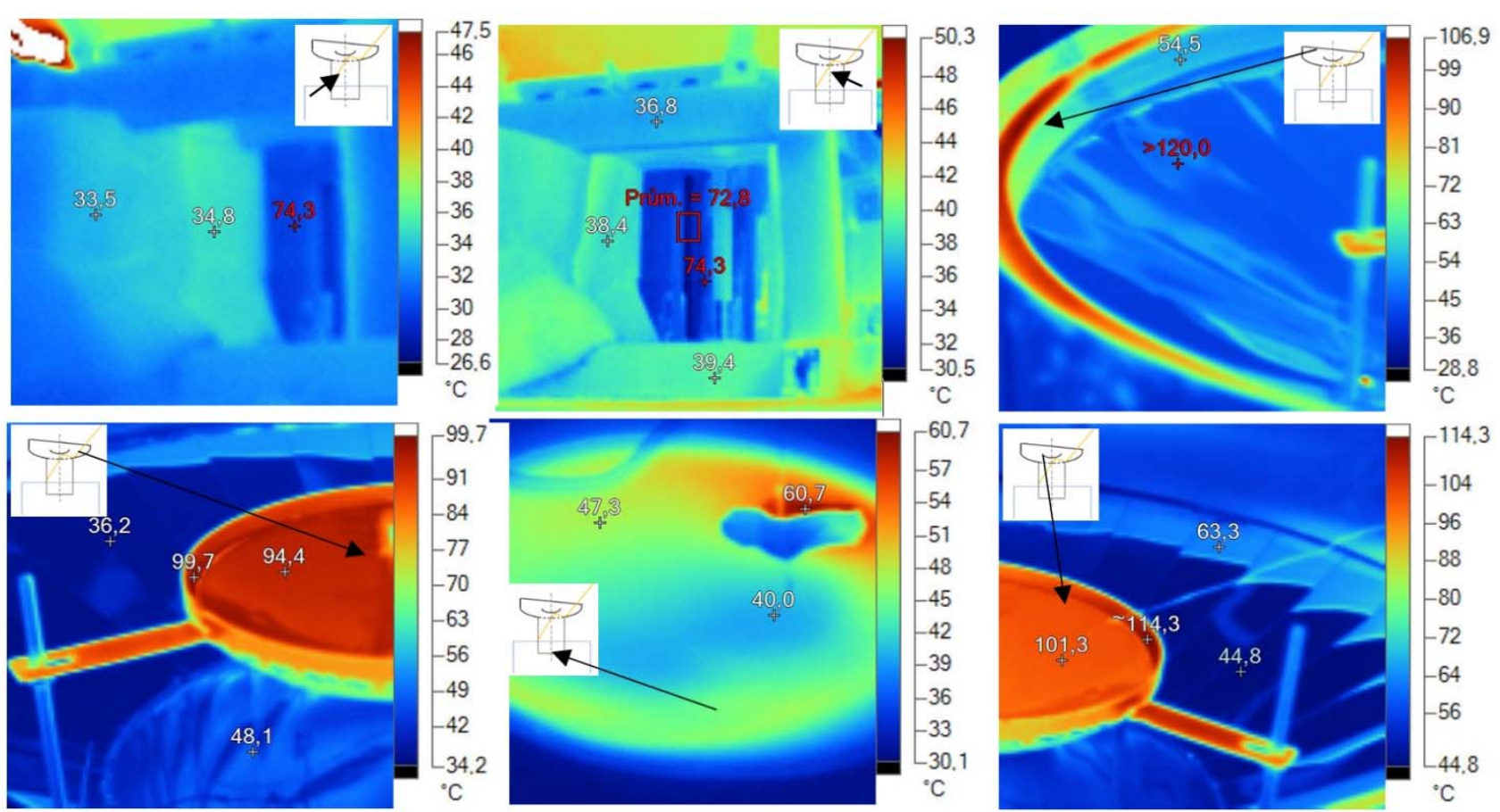

Figure 8. IR thermography of the thermally insulated light pipe (thermal insulation was demounted directly before the monitoring). 
Table 2. Temperature difference between internal and external parts of the light pipe parabolic head

\begin{tabular}{|l|l|}
\hline $\begin{array}{l}\text { Internal surface - } \\
\text { diffuser }\end{array}$ & $\begin{array}{l}\text { External surface - } \\
\text { parabolic mirrors }\end{array}$ \\
\hline Max $60.7^{\circ} \mathrm{C}$ & Max $120^{\circ} \mathrm{C}$ \\
\hline Min $30.3^{\circ} \mathrm{C}$ & Min $44.8^{\circ} \mathrm{C}$ \\
\hline Average $48.5^{\circ} \mathrm{C}$ & Average $82.3^{\circ} \mathrm{C}$ \\
\hline
\end{tabular}

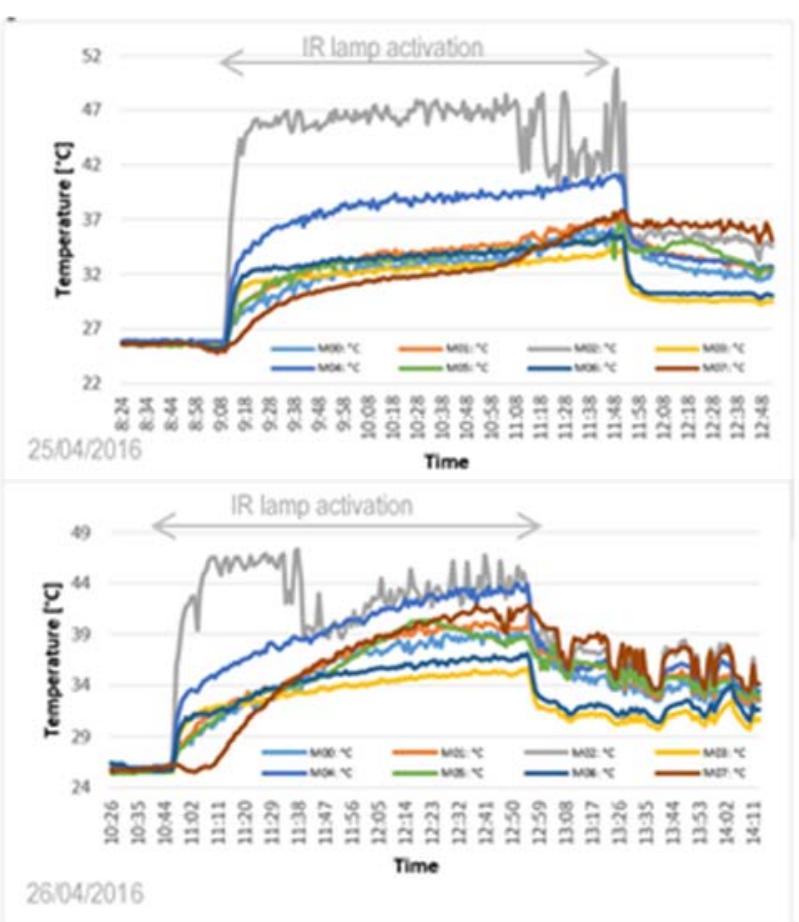

Figure 9. The light pipe temperature profiles (M00 indoor air, M01 - Position I, M02 Position II, M03 - Position III, M04 Position IV, M05 - Position V, M06 Position VI, M07 - Position VII).

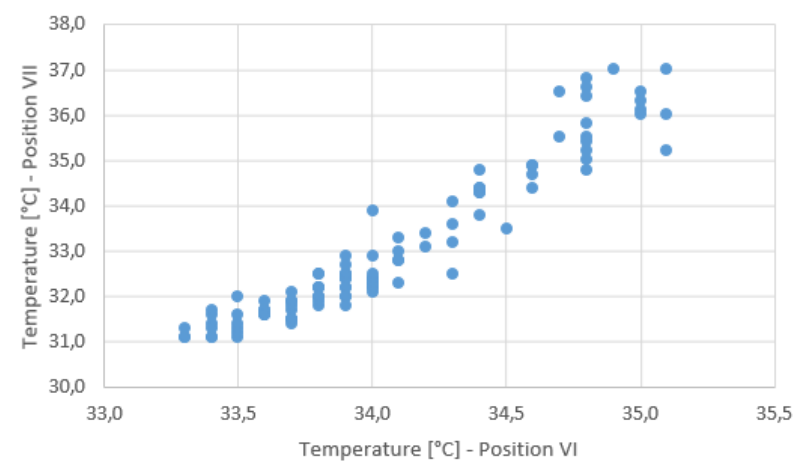

Figure 10. Correlation between temperatures measured at Positions VI and VII.

\section{Conclusion}

The testing of the light pipe prototype gives an overview about temperature distribution under intensive infrared radiation. The infrared thermography photographs show very high temperature on concentrator head. The temperature on the diffuser inside the box has increased significantly as well. It seems that the air trapped inside of the tube was warmed under the infrared radiation.

The temperature raised up to $40^{\circ} \mathrm{C}$ due to the infrared lamp activation for light pipe installation without thermal insulation of the surface. In the case of the thermally insulated light pipe, the surface temperature raised up to $74^{\circ} \mathrm{C}$ and in some places even more. The highest temperature distribution was on the parabolic concentrator heat $\left(100-120^{\circ} \mathrm{C}\right)$. Also data from temperature measurements show significant temperature rise on the light pipe surface in the response to the infrared radiation.

The above mentioned findings show potential problems of the light pipe overheating under intensive solar radiation in summer seasons. For this reason the light pipe system application in real buildings should be completed carefully in details regarding connections with roof and floor structures. It is recommended to add thermal insulation layers round the light pipe and underneath of the parabolic concentrator. The insulation should be nonflammable and the details of the light pipe head pipe and diffuser should be completed to be perfectly sealed and fire resistant. In the case of extremely thermal loading transparent parts of the light pipe are recommended to be completed with fire resistant laminated glass. The system of the light pipe could be completed with additional ventilated pipe for the overheating prevention.

The contribution of the presented thermal evaluations of the light pipe prototype is:

- testing of the temperature distribution of the new light pipe prototype,

- specification of temperature profiles of air inside of the light pipe and close to the parabolic head,

- specification of potential overheating problems in building applications.

The further investigation and thermal testing of the light pipe prototype is going to compare the presented results with the thermal monitoring of the prototype installed in a roof construction. The installation will be with positioning of the light parabolic concentrator towards the south orientation to 
maximize solar and the system efficiency and testing potential places of overheating in real building constructions.

\section{Acknowledgement}

This article has been worked under the project No. LO1408 "AdMaS UP - Advanced Materials, Structures and Technologies", supported by Ministry of Education, Youth and Sports under the „National Sustainability Programme I". The authors acknowledge company Lightway for the light pipe prototype and support of the light measurements and testing.

\section{References}

[1] Hough T. P. (ed.): Trends in Solar Energy Research, Nova Science Publisher, New York 2006.

[2] Robertson, K.: Daylighting Guide for Buildings. Daylighting Guide for Canadian Commercial Buildings, NRCan, NRCC 2002. Online guide Lightswitch Wizard, NRCan, NRCC, 2003. www.buildwiz.com.

[3] Boyce, P. R.: Human factors in daylighting, CRC Press, Taylor \& Francis Group, New York, 2014.

[4] Dumitrescu, L. et al.: The Influence of Thermal Bridgesin the Process of Buildings Thermal Rehabilitation, Procedia Engineering, 181 (2017), 682-689.

[5] Ge, H, Baba, F.: Dynamic effect of thermal bridges on the energy performance of a low-rise residential building, Energy and Buildings, 15 (2015), 106-118.

[6] Li, J. et al.: Experimental Study on the Influence of Daylighting Performance of Solar Light Pipes by Dusts and Condensation, Advanced Materials Research, (2011), 1096-1099.

[7] Dengel, A., Swainson, M. et al.: Overheating in dwellings, 116885 Overheating Guidance. BRE Watford 2016.

[8] Tiwari, G. N. et al.: Handbook of Solar Energy: Theory, Analysis and Applications, Springer, Science+Business Media, Singapore, 2016.

[9] Swift, P. D., and Smith, G. B.: Cylindrical Mirror Light Pipes, Solar Energy Materials and Solar Cells, 36 (1995), 159-168.

[10] Shao, L., Riffat, S.: Daylighting using light pipes and its integration with solar heating and natural ventilation, Lighting Research and Technology, 32 (2000) 3,133-139.

[11] Taengchum, T. et al:: Tracing of daylight through circular light pipes with anidolic concentrators, Solar Energy 110 (2014), 818-829.

[12] Nair, N.G. et al.: Design of an anidolic concentrator and evaluation of daylight enhancement under an overcast sky, Lighting Research \& Technology 48(2015) 8, 917-929.

[13] Fiorentinia, L. et al.: Fire Risk Assessment of Photovoltaic Plants. A Case Study Moving from two Large Fires: from Accident Investigation and Forensic Engineering to Fire Risk Assessment for Reconstruction and Permitting Purposes, Chemical Engineering Transactions, 48 (2016), 247-232.

[14] Laukamp, H., et al.: PV fire hazard - Analysis and Assessment of Fire Incidents, The $28^{\text {th }} \mathrm{EU}$ PVSEC, Paris, 2013.

[15] Light pipe, www.lightway.cz (18/12/2017).

[16] Edmonds, I.R., et al.: Daylighting enhancement with light pipes coupled to laser-cut lightdeflecting panels, Lighting Research Technology, 27 (1995), 27-35.

[17] Carter, J.: Developments in tubular daylight guidance systems, Building Research Information, 32 (2004) 3, 220-234.

[18] Aizenberg, J. B.: Hollow light guides: 50 Years of research, development, manufacture and application - a retrospective and looking to the future, Light and Engineering, 21 (2004) 4, 2125.

[19] Kocifaj, M., Darula, S., Kittler, R.: Holigilm: hollow light guide interior illumination method - an analytic calculation approach for cylindrical light-tubes, Solar Energy, 82 (2008) 3, 247-59.

[20] Mohelníkova, J.: Evaluation of indoor illuminance from light guides, Journal of Light and Visual Environment, 32 (2008) 1, 20-26.

[21] McCluney, R.: Rating of Tubular Daylighting Devices for Visible Transmittance and Solar Heat Gain. Final Report, FSEC-CR-1385-03, Florida Solar Energy Center, 2003.

[22] Bencs, P., et al.: Simultaneous measurement of velocity and temperature field downstream of a heated cylinder, Engineering Review, 34 (2014) 1, 3-17.

[23] Perčić, M., et al.: A three-dimensional numerical analysis of complete crossflow heat exchangers 
with conjugate heat transfer, Engineering Review, 33 (2013) 1, 23-40.

[24] Harrison, S.J. , McCurdy, G.G., Cooke, R.: Preliminary evaluation of the daylighting and thermal performance of cylindrical skylights, Proceedings of International Daylight Conference 1998 Ottawa, 205-212.

[25] Callow, J.M.: Daylighting Using Tubular Light Guide Systems, Ph.D. Thesis, University of Nottingham, 2003.

[26] Williams, D.A., Dorville, J.F.: Investigating the Thermal and Lighting Performance of Light Pipes for Sunny and Cloudy Conditions in Insular Tropical Climate, Journal of Electrical Engineering, 2 (2014), 221-227.

[27] Šikula, O. et al.: Thermal CFD analysis of tubular light guides, Energies, 6 (2013), 12, 6304-6321.

[28] Šikula, O., et al.: Thermal analysis of light pipes for insulated flat roofs, Energy and Buildings 85 (2014), 436-444.

[29] Varga, S.; Oliveira, A.C.: Ventilation terminals for use with light pipes in buildings: A CFD study, Applied Thermal Engineering, 20 (2000), 1743-1752.

[30] Ait-taleb, T. et al.: Numerical simulation of coupled heat transfers by conduction, natural convection and radiation in hollow structures heated from below or above, International Journal of Thermal Sciences, 47 (2008) 4, 378387.

[31] Tillenkamp, F.: Integrated Light Pipe/Passive Stack Ventilation/Solar Heating Cooling Unit on Pilot-Plant Scale (TRIPLESAVE Unit) and Related Know How. In Community Research and Development Information Service; CORDIS: Winterthur, Suisse, 2003; Available online: $\mathrm{http}: / /$ cordis.europa.eu/result/report/ren/ 26896 de.html (accessed on 22 August 2013).

[32] Oliveira, A.C. et al.: Experimental and numerical analysis of natural ventilation with combined light/vent pipes, Applied Thermal Engineering, 21 (2001), 1925-1936.
[33] Taengchum, T. et al.: A study on a ventilation stack integrated with a light pipe. Applied Thermal Engineering, 50 (2013), 546-554.

[34] Daylighting Devices, Engineering Reference EnergyPlus 8.0, http://bigladdersoftware.com/epx/docs/80/engineering-reference/page-042.html

[35] Mohelnikova, J.: Method for evaluation of radiative properties of glass samples, Applied Thermal Engineering, 28 (2008), 5-6, 388-395.

[36] Athienitis, A.K. Samtamouris, M.: Thermal Analysis and Design of Passive Solar Buildings, Earthscan, Routledge, Abingdon, 2013.

[37] Balaras, C.A., Argiriou. A.A.: Infrared thermography for building diagnostics, Energy and Buildings, 34(2005), 2, 171-183.

[38] Barreira, E, et. al.: Evaluation of building materials using infrared thermography, Construction and Building Materials, 21 (2007) 1, 218-224.

[39] Blecich, P., et al.: Application of Infrared Camera in Thermal Engineering, Engineering Review, 29 (2009) 1, 47-59.

[40] Lamp RRW 4500 Quartz halogen infrared zone/spot heating, Red Rat Engineering, Ltd.

[41] European Solar Thermal Industry Federation: ESTIF. http://www.estif.org/(18/12/2017).

[42] Flir ThermaCAM PM695, http://www.flir.com/legacy/view/?id=51533.

[43] Thermoworks/Emissivity table http://www.thermoworks.com/emissivity_table $(17 / 12 / 2017)$.

[44] Türler, D., et al.: STP1320 Laboratory Procedures for Using Infrared Thermography to Validate Heat Transfer Models, in STP1320 Insulation Materials: Testing and Applications, $3^{\text {rd }}$ Volume, ASTM, Ann Arbor 1997.

[45] Data-Logger Almemo, Ahlborn https://www.ahlborn.cz/pristroje/mericiustredny-almemo/

[46] BS EN 60584-1:2013 Thermocouples. EMF specifications and tolerances. 